Article

\title{
A High Dietary Incorporation Level of Chlorella vulgaris Improves the Nutritional Value of Pork Fat without Impairing the Performance of Finishing Pigs
}

\author{
Diogo Coelho ${ }^{1}{ }^{\oplus}$, José Pestana ${ }^{1}$, João M. Almeida ${ }^{2}{ }^{\oplus}$, Cristina M. Alfaia ${ }^{1}$, \\ Carlos M. G. A. Fontes ${ }^{1}$, Olga Moreira ${ }^{2} \mathbb{D}$ and José A. M. Prates ${ }^{1, *(D)}$ \\ 1 CIISA-Centro de Investigação Interdisciplinar em Sanidade Animal, Faculdade de Medicina Veterinária, \\ Universidade de Lisboa, 1300-477 Lisboa, Portugal; diogocoelho@fmv.ulisboa.pt (D.C.); \\ jpestana@fmv.ulisboa.pt (J.P.); cpmateus@fmv.ulisboa.pt (C.M.A.); cafontes@fmv.ulisboa.pt (C.M.G.A.F.) \\ 2 INIAV-Instituto Nacional de Investigação Agrária e Veterinária, Fonte Boa, \\ 2005-048 Vale de Santarém, Portugal; joaoalmeida@iniav.pt (J.M.A.); olga.moreira@iniav.pt (O.M.) \\ * Correspondence: japrates@fmv.ulisboa.pt
}

Received: 5 November 2020; Accepted: 10 December 2020; Published: 12 December 2020

Simple Summary: Pork is one of the most consumed meats worldwide but its production and quality are facing significant challenges, including feeding sustainability and the unhealthy image of fat. In fact, corn, and soybean, the two main conventional feedstuffs for pig production, are in unsustainable competition with the human food supply and biofuel industry. Moreover, the nutritional value of pork lipids is small due to their low contents of the beneficial $n-3$ polyunsaturated fatty acids and lipid-soluble antioxidants. The inclusion of microalgae in pig diets represents a promising approach for the development of sustainable pork production and the improvement of its quality. The current study aimed to investigate the impact of Chlorella vulgaris as ingredient ( $5 \%$ in the diet), alone and in combination with carbohydrases, on growth performance, carcass characteristics and pork quality traits in finishing pigs. Our data indicate that the use of $5 \%$. vulgaris in finishing pig diets does not impair animal growth and ameliorates the nutritional value of pork. Therefore, C. vulgaris could be used advantageously as an alternative sustainable ingredient in swine feeding.

\begin{abstract}
The influence of a high inclusion level of Chlorella vulgaris, individually and supplemented with two carbohydrase mixtures, in finishing pig diets was assessed on zootechnical performance, carcass characteristics, pork quality traits and nutritional value of pork fat. Forty crossbred entire male pigs, sons of Large White $\times$ Landrace sows crossed with Pietrain boars, with an initial live weight of $59.1 \pm 5.69 \mathrm{~kg}$ were used in this trial. Swines were randomly assigned to one of four dietary treatments $(n=10)$ : cereal and soybean meal-based diet (control), control diet with $5 \%$ C. vulgaris (CV), CV diet supplemented with $0.005 \%$ Rovabio ${ }^{\circledR}$ Excel AP $(\mathrm{CV}+\mathrm{R})$ and $\mathrm{CV}$ diet supplemented with $0.01 \%$ of a four-CAZyme mixture $(C V+M)$. Animals were slaughtered, after the finishing period, with a BW of $101 \pm 1.9 \mathrm{~kg}$. Growth performance, carcass characteristics and meat quality traits were not influenced $(p>0.05)$ by the incorporation of $C$. vulgaris in the diets. However, the inclusion of the microalga in finishing pig diets increased some lipid-soluble antioxidant pigments and $n-3$ PUFA, and decreased the $n-6: n-3$ ratio of fatty acids, thus ameliorating the nutritional value of pork fat. Moreover, the supplementation of diets with the carbohydrase mixtures did not change $(p>0.05)$ neither animal performance nor meat quality traits, indicating their inefficacy in the increase of digestive utilization of $C$. vulgaris by pigs under these experimental conditions. It is concluded that the use of $C$. vulgaris in finishing pig diets, at this high incorporation level, improves the nutritional value of pork fat without compromising pig performance.
\end{abstract}


Keywords: Chlorella vulgaris; CAZymes; finishing pigs; growth performance; pork quality; fat composition

\section{Introduction}

Pork industry is currently facing the big challenges of feeding sustainability and the unhealthy image of fat. In fact, pork production is about $38 \%$ of the total amount of meat produced in the world, being is the most commonly consumed meat in different European, American, and Asian countries [1]. Moreover, the combination between rise of global population and the increase in income, will double the overall demand for animal-derived products by 2050, including pork [2]. The increased demand for these products will necessarily bring dramatic consequences in terms of sustainability, as cereal grains and soybean food crops are the two main conventional feedstuffs for animal feeding [3]. Therefore, alternative feed ingredients are needed to sustain animal agriculture and human food security $[4,5]$.

In addition, pork is frequently considered unhealthy due to the lower proportions of polyunsaturated fatty acids (PUFA) and lipid-soluble antioxidant vitamins, and higher percentages of saturated fatty acids (SFA) [6]. However, it is well established that pig diet provides an effective approach for altering the fat composition of pork, thereby modifying the impact of human dietary fat intake from pork [7]. Functionally, the most important $n-3$ fatty acids are eicosapentaenoic acid (EPA, 20:5n-3) and docosahexaenoic acid (DHA, 22:6n-3), although the roles for docosapentaenoic acid (DPA, 22:5n-3) are now also emerging [8]. Lipid-soluble antioxidant vitamins comprise vitamin E homologues (tocopherols and tocotrienols) and vitamin A and its precursors (some carotenoids, including $\beta$-carotene). In general, the intakes of EPA and DHA are typically small and much lower than the recommended values [9]. This fact raised substantial interest in food enrichment with EPA and DHA, by using feed ingredients from marine origin in animal nutrition.

Microalgae, an important aquatic resource, could be a good sustainable alternative to conventional feedstuffs, since they have similar nutritional compositions [10]. Chlorella vulgaris is a freshwater eukaryotic green microalga. This microalga, one of the most cultivated microalgae worldwide, is known for its high biomass productivity, relative ease of cultivation and a balanced nutritional composition, making it an attractive alternative for monogastric diets [11]. In particular, regarding fatty acid profile, $C$. vulgaris displays a high percentage of SFA, mainly myristic acid (14:0), palmitic acid (16:0) and stearic acid (18:0). In addition, $C$. vulgaris presents an interesting content in some $n-6$ PUFA (18:2n-6 and 18:3n-6) and $\alpha$-linolenic acid (18:3n-3), but much less quantity of EPA and DHA [12]. However, $C$. vulgaris cell wall is composed by a diverse and complex matrix of cross-linked insoluble carbohydrates [13]. Thus, the incorporation of $C$. vulgaris in monogastric diets could be a problem since the recalcitrant cell wall is largely indigestible, impairing the bioavailability of its valuable nutrients [14].

Exogenous carbohydrate-active enzymes (CAZymes) are now completely accepted as feed supplements for monogastric livestock species to improve feed nutritive value and enhance animal performance and health [15]. In addition to cereal cell walls, several in vitro studies demonstrated the ability of CAZymes to degrade microalgae cell walls [16-19]. Recently, Coelho et al. [20] described a four-CAZyme mixture, composed by an exo- $\beta$-glucosaminidase, an alginate lyase, a peptidoglycan $\mathrm{N}$-acetylmuramic acid deacetylase and a lysozyme, that was shown to disrupt microalgae $C$. vulgaris cell walls to a significant extent, in in vitro assays, enabling the release of trapped nutrients with important nutritional value.

Therefore, the supplementation with the four-CAZyme mixture mentioned above could enable the incorporation of $C$. vulgaris in monogastric diets, at high incorporation levels ( $>2 \%$ in diet), without impairing animal performance and health. In line with this, the aim of this study was to assess how the dietary incorporation of $C$. vulgaris at a 5\% high level, supplemented or not with two exogenous CAZyme mixtures (the commercially available Rovabio ${ }^{\circledR}$ Excel (ADISSEO, Antony, 
France) AP and the four-CAZyme mixture described by Coelho et al. [20]), influences finishing pigs' performance, carcass characteristics, and pork quality traits.

\section{Materials and Methods}

\subsection{Production of Recombinant Four-CAZyme Mixture}

The genes encoding the four recombinant CAZymes that compose the mixture (exo- $\beta$-glucosaminidase, alginate lyase, peptidoglycan $\mathrm{N}$-acetylmuramic acid deacetylase and lysozyme) were cloned according to Coelho et al. [20]. Briefly, BL21 Escherichia coli cells were transformed with the generated recombinant plasmids and were grown on Luria-Bertani media, at $37^{\circ} \mathrm{C}$ under agitation $(190 \mathrm{rpm}$ ) to mid exponential phase (absorbance was measured at $\lambda=595 \mathrm{~nm}$ as being 0.4-0.6). Isopropyl $\beta$-d-thiogalactoside was added to a final concentration of $1 \mathrm{mM}$ in order to induce recombinant gene expression. Cells were incubated overnight at $19{ }^{\circ} \mathrm{C}$ with agitation $(140 \mathrm{rpm})$. After induction, the culture media was centrifuged and the protein extracts were prepared by ultrasonication, followed by centrifugation and freeze dried. The four-CAZyme protein extracts were mixed in equal weight proportions at a final level of $0.01 \%$.

\subsection{Animal Care, Experimental Design and Experimental Diets}

The trial was conducted at the facilities of Unidade de Investigação em Produção Animal (Instituto Nacional de Investigação Agrária e Veterinária (UEISPA-INIAV, Santarém). The experimental procedures were reviewed by the Ethics Commission of the Centro de Investigação Interdisciplinar em Sanidade Animal/Faculdade de Medicina Veterinária (CIISA/FMV) and approved by the Animal Care Committee of the National Veterinary Authority (Direção-Geral de Alimentação e Veterinária), following the appropriated European Union guidelines (2010/63/EU Directive). The staff members involved in animal trial hold license for conducting experiments on live animals from the Portuguese Veterinary Services.

Forty crossbred entire male pigs, sons of Large White $\times$ Landrace sows crossed with Pietrain boars, were obtained from a commercial farm. Before the beginning of the trial, pigs were submitted to an adaptation period of one week. Then, pigs with an initial weight of $59.1 \pm 5.69 \mathrm{~kg}$ were randomly distributed into 10 pens with 4 animals in each pen $\left(7.8 \mathrm{~m}^{2}\right)$. Pens were equipped with one stainless steel nipple and four creep feeders separated by a system of gates, thus allowing individual feed intake control. The 4 experimental diets were randomly assigned to the four animals within each pen, with each animal in each pen receiving a different diet, thus being the pig the experimental unit. Pigs had access to feed and water ad libitum. The experimental diets were: cereal and soybean meal-based diet (Control), control diet with 5\% of C. vulgaris supplied by Allmicroalgae (Natural Products, Portugal) (CV), control diet with $5 \%$ of $C$. vulgaris supplemented with $0.005 \%$ of Rovabio ${ }^{\circledR}$ Excel AP (Adisseo, Antony, France) $(C V+R)$, and control diet with $5 \%$ of $C$. vulgaris supplemented with $0.01 \%$ of four-CAZyme mixture $(\mathrm{CV}+\mathrm{M})$.

The ingredient composition of the experimental diets is described in Table 1 , and their chemical composition is presented in detail in Table 2. For further information on the feed analysis see details below. 
Table 1. Ingredients and additives of the experimental diets (\%, as fed basis).

\begin{tabular}{|c|c|c|c|c|}
\hline \multirow{2}{*}{ Ingredients (\%) } & \multicolumn{4}{|c|}{ Experimental Diets } \\
\hline & Control & $\mathrm{CV}$ & $\mathrm{CV}+\mathrm{R}$ & $\mathrm{CV}+\mathrm{M}$ \\
\hline Corn & 56 & 56 & 56 & 56 \\
\hline Soybean meal & 19.3 & 11.7 & 11.6 & 11.7 \\
\hline Barley & 10 & 10 & 10 & 10 \\
\hline Sunflower meal & 5.4 & 6.8 & 6.8 & 6.8 \\
\hline Wheat & 5 & 5 & 5 & 5 \\
\hline Calcium carbonate & 1.3 & 1.2 & 1.2 & 1.2 \\
\hline Soybean oil & 0.5 & 0.2 & 0.2 & 0.2 \\
\hline Wheat bran & 0.4 & 1.7 & 1.66 & 1.65 \\
\hline Salt & 0.4 & 0.4 & 0.4 & 0.4 \\
\hline Vitamin-trace mineral premix ${ }^{1}$ & 0.4 & 0.4 & 0.4 & 0.4 \\
\hline Dicalcium phosphate & 0.26 & 0.36 & 0.36 & 0.36 \\
\hline Sodium bicarbonate & 0.1 & 0.1 & 0.1 & 0.1 \\
\hline Betaine-HCl & 0.15 & 0.15 & 0.15 & 0.15 \\
\hline Mold inhibitor mixture ${ }^{2}$ & 0.075 & 0.075 & 0.075 & 0.075 \\
\hline Fatty acid mixture ${ }^{3}$ & 0.075 & 0.075 & 0.075 & 0.075 \\
\hline L-Lysine & 0.41 & 0.57 & 0.57 & 0.57 \\
\hline L-Threonine & 0.1180 & 0.2000 & 0.2000 & 0.2000 \\
\hline DL-Methionine & 0.0712 & 0.1080 & 0.1080 & 0.1080 \\
\hline L-Tryptophan & 0.0064 & - & - & - \\
\hline Chlorella vulgaris & - & 5 & 5 & 5 \\
\hline Mix of 4 CAZymes & - & - & - & 0.01 \\
\hline Rovabio ${ }^{\circledR}$ Excel AP & - & - & 0.005 & - \\
\hline
\end{tabular}

Experimental diets: Control-corn-soybean basal diet; CV-basal diet plus 5\% C. vulgaris; $\mathrm{CV}+\mathrm{R}$-basal diet plus $5 \%$ C. vulgaris $+0.005 \%$ Rovabio ${ }^{\circledR}$ Excel AP; CV + M-basal diet plus $5 \%$ C. vulgaris $+0.01 \%$ mix of 4 CAZymes. ${ }^{1}$ VitaTec (Tecadi, Santarém, Portugal). Provided the following nutrients per $\mathrm{kg}$ of diet: Premix provided per $\mathrm{kg}$ of complete

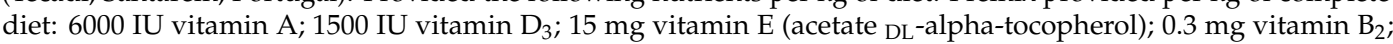
$3.75 \mathrm{mg}$ vitamin $\mathrm{B}_{12} ; 0.1 \mathrm{mg}$ biotin; $12 \mathrm{mg}$ calcium pantothenate, $15 \mathrm{mg}$ nicotinic acid; $0.75 \mathrm{mg}$ folic acid; $200 \mathrm{mg}$ choline chloride; $15 \mathrm{mg} \mathrm{Cu}$ (cupric sulphate pentahydrate); $100 \mathrm{mg} \mathrm{Zn} \mathrm{(zinc} \mathrm{oxide);} 35 \mathrm{mg} \mathrm{Mn}$ (manganese oxide); $0.7 \mathrm{mg}$ I (potassium iodide); $0.05 \mathrm{mg}$ Co (basic cobaltous carbonate mono hydrous); $0.2 \mathrm{mg}$ Se (sodium selenite); $80 \mathrm{mg}$ Fe(ferrous carbonate); and $0.2 \mathrm{mg}$ butylated hydroxyl-toluene. ${ }^{2}$ Yeast extracts, high absorbent clay mineral, plant derivatives, calcium propionate and antioxidant premix (Escent ${ }^{\circledR} \mathrm{S}$, Innovad, Berchem, Belgium). ${ }^{3}$ Esterified butyric acid, medium chain fatty acid, plant extract and essential oil (Lumance ${ }^{\circledR}$, Innovad, Berchem, Belgium).

Table 2. Chemical composition of Chlorella vulgaris and experimental diets.

\begin{tabular}{cccccc}
\hline \multirow{2}{*}{ Item } & Microalga C. vulgaris & \multicolumn{4}{c}{ Experimental Diets } \\
\cline { 3 - 5 } & & Control & $\mathbf{C V}$ & $\mathbf{C V}+\mathbf{R}$ & $\mathbf{C V}+\mathbf{M}$ \\
\hline ME, kcal/kg DM & & 3576 & 3540 & 3644 & 3547 \\
& 3557 & Proximate composition, \% & & & \\
Dry matter & 93.1 & 90.0 & 89.7 & 89.5 & 90.0 \\
Crude protein & 42.8 & 14.0 & 15.9 & 15.2 & 15.2 \\
Starch & 1.86 & 45.5 & 45.3 & 44.7 & 47.4 \\
Crude fat & 8.73 & 2.60 & 3.00 & 3.10 & 3.10 \\
Crude fiber & 1.52 & 4.60 & 5.00 & 5.30 & 5.20 \\
NDF & 1.05 & 13.7 & 13.9 & 12.7 & 13.7 \\
ADF & 0.286 & 4.90 & 5.50 & 5.50 & 5.90 \\
Ash & 11.8 & 4.03 & 4.70 & 4.60 & 4.60 \\
\hline
\end{tabular}


Table 2. Cont.

\begin{tabular}{|c|c|c|c|c|c|}
\hline \multirow{2}{*}{ Item } & \multirow{2}{*}{ Microalga C. vulgaris } & \multicolumn{4}{|c|}{ Experimental Diets } \\
\hline & & Control & $\mathrm{CV}$ & $\mathrm{CV}+\mathrm{R}$ & $\mathrm{CV}+\mathrm{M}$ \\
\hline \multicolumn{6}{|c|}{ Amino acid composition, $\%$} \\
\hline Alanine & 2.77 & 0.682 & 0.848 & 0.806 & 0.776 \\
\hline Arginine & 3.89 & 0.890 & 1.11 & 1.03 & 0.969 \\
\hline Asparagine & 0.062 & 0.023 & 0.022 & 0.015 & 0.018 \\
\hline Aspartate & 3.04 & 1.00 & 1.08 & 1.11 & 1.01 \\
\hline Cysteine & 0.665 & 0.292 & 0.268 & 0.237 & 0.248 \\
\hline Glutamate & 4.07 & 2.33 & 2.22 & 2.21 & 2.10 \\
\hline Glutamine & 0.016 & nd & nd & nd & nd \\
\hline Glycine & 1.72 & 0.544 & 0.687 & 0.614 & 0.584 \\
\hline Histidine & 0.654 & 0.512 & 0.593 & 0.528 & 0.489 \\
\hline Hydroxyproline & 0.741 & 0.880 & 1.33 & 1.19 & 1.16 \\
\hline Isoleucine & 1.26 & 0.478 & 0.536 & 0.521 & 0.482 \\
\hline Leucine & 2.45 & 0.942 & 1.05 & 1.03 & 0.984 \\
\hline Lysine & 2.63 & 1.04 & 1.43 & 1.42 & 1.32 \\
\hline Methionine & 0.451 & 0.116 & 0.124 & 0.144 & 0.088 \\
\hline Phenylalanine & 1.49 & 0.578 & 0.634 & 0.621 & 0.587 \\
\hline Proline & 1.87 & 1.06 & 1.04 & 1.04 & 1.01 \\
\hline Serine & 1.56 & 0.689 & 0.771 & 0.727 & 0.679 \\
\hline Threonine & 2.32 & 0.761 & 0.989 & 1.00 & 0.943 \\
\hline Tryptophan & 0.471 & 0.156 & 0.172 & 0.147 & 0.133 \\
\hline Tyrosine & 1.18 & 0.429 & 0.495 & 0.470 & 0.437 \\
\hline Valine & 3.52 & 1.20 & 1.43 & 1.32 & 1.26 \\
\hline \multicolumn{6}{|c|}{ Fatty acid profile, $\%$ total fatty acids } \\
\hline $14: 0$ & 1.13 & 0.150 & 0.218 & 0.190 & 0.190 \\
\hline $16: 0$ & 17.2 & 16.3 & 16.6 & 16.3 & 16.5 \\
\hline $16: 1 c 9$ & 3.90 & 0.228 & 1.14 & 0.989 & 0.972 \\
\hline 17:0 & 0.234 & 0.189 & 0.182 & 0.153 & 0.154 \\
\hline $17: 1 c 9$ & 0.610 & 0.038 & 0.704 & 0.739 & 0.732 \\
\hline 18:0 & 3.00 & 2.89 & 3.29 & 3.11 & 3.08 \\
\hline $18: 1 c 9$ & 11.7 & 27.4 & 27.4 & 27.6 & 27.5 \\
\hline $18: 1 c 11$ & nd & 0.885 & 1.70 & 1.38 & 1.42 \\
\hline $18: 2 n-6$ & 11.2 & 48.1 & 44.1 & 45.1 & 44.9 \\
\hline $18: 3 n-3$ & 10.1 & 2.57 & 3.47 & 3.28 & 3.28 \\
\hline 20:0 & 0.174 & 0.528 & 0.513 & 0.517 & 0.500 \\
\hline $20: 1 c 11$ & 0.127 & 0.292 & 0.288 & 0.320 & 0.320 \\
\hline $20: 5 n-3$ & nd & nd & nd & nd & nd \\
\hline $22: 0$ & 0.060 & 0.304 & 0.294 & 0.262 & 0.266 \\
\hline $22: 1 n-9$ & nd & 0.155 & 0.155 & 0.131 & 0.149 \\
\hline $22: 6 n-3$ & nd & nd & nd & nd & nd \\
\hline \multicolumn{6}{|c|}{ Diterpene profile, $\mu \mathrm{g} / \mathrm{g}$} \\
\hline$\alpha$-Tocopherol & 19.2 & 16.5 & 18.7 & 19.4 & 16.5 \\
\hline$\alpha$-Tocotrienol & nd & 4.84 & 3.70 & 3.88 & 4.36 \\
\hline$\beta$-Tocopherol & 0.340 & 0.380 & 0.268 & 0.244 & 0.258 \\
\hline$\gamma$-Tocopherol & 0.520 & 3.53 & 2.74 & 2.35 & 2.65 \\
\hline$\gamma$-Tocotrienol & 0.560 & 7.23 & 5.93 & 7.30 & 6.02 \\
\hline$\delta$-Tocopherol & 0.360 & 0.340 & 0.331 & 0.312 & 0.314 \\
\hline$\delta$-Tocotrienol & nd & 0.287 & 0.230 & 0.246 & 0.247 \\
\hline \multicolumn{6}{|c|}{ Pigments, $\mu \mathrm{g} / \mathrm{g}$} \\
\hline$\beta$-Carotene & 198 & 1.19 & 7.10 & 7.40 & 6.49 \\
\hline Chlorophyll $a^{2}$ & 906 & 4.31 & 127 & 139 & 126 \\
\hline Chlorophyll $b^{3}$ & 171 & 7.46 & 33.9 & 36.6 & 34.2 \\
\hline Total Chlorophylls ${ }^{4}$ & 1077 & 11.8 & 161 & 176 & 160 \\
\hline Total Carotenoids 5 & 228 & 3.97 & 36.5 & 39.5 & 34.9 \\
\hline $\begin{array}{l}\text { Total Chlorophylls+ } \\
\text { carotenoids } 6^{6}\end{array}$ & 1305 & 15.7 & 198 & 215 & 195 \\
\hline
\end{tabular}

Experimental diets: Control-corn-soybean basal diet; CV-basal diet plus $5 \%$ C. vulgaris; $C V+R$-basal diet plus $5 \%$ C. vulgaris $+0.005 \%$ Rovabio ${ }^{\circledR}$ Excel AP; CV + M-basal diet plus $5 \%$ C. vulgaris $+0.01 \%$ mix of 4 CAZymes. ME-metabolized energy; DM-dry matter; NDF-neutral detergent fiber; ADF-acid detergent fiber; nd-not detected. ${ }^{1}$ Metabolizable energy $(\mathrm{kcal} / \mathrm{kg} \mathrm{DM})=4412-11.06 \times$ Ash $(\mathrm{g} / \mathrm{kg} \mathrm{DM})+3.37 \times$ Crude Fat $(\mathrm{g} / \mathrm{kg} \mathrm{DM})-5.18 \times$ $\mathrm{ADF}(\mathrm{g} / \mathrm{kg} \mathrm{DM}) .{ }^{2}$ Chlorophyll $a=11.24 \times$ A662 nm $-2.04 \times$ A645 nm. ${ }^{3}$ Chlorophyll $b=20.13 \times$ A645 nm $-4.19 \times$ A662 nm. ${ }^{4}$ Total chlorophylls $(\mathrm{Ca}+\mathrm{b})=7.05 \times$ A662 nm $+18.09 \times$ A645 nm. ${ }^{5}$ Total carotenoids $(\mathrm{Cx}+\mathrm{c})=(1000 \times$ A470 $\mathrm{nm}-1.90 \times \mathrm{Ca}-63.14 \times \mathrm{Cb}) / 214 .{ }^{6}$ Total chlorophylls and carotenoids $=(\mathrm{Ca}+\mathrm{b})+(\mathrm{Cx}+\mathrm{c})$. 


\subsection{Animal Performance, Slaughter, and Sampling}

During the experiment, supplied feed and refusals were recorded daily, whereas pig were weighed weekly just before feeding, with the purpose of calculate average daily feed intake (ADFI), average daily weight gain (ADG), feed conversion ratio (FCR) and gain:feed ratio (G:F). Food was withdrawn from animals 17-19 h before slaughter. Animals were slaughtered at a BW of $101 \pm 1.9 \mathrm{~kg}$, after a trial period of $41 \pm 7.8$ days, at the Unidade de Investigação em Produção Animal experimental slaughterhouse (Santarém, Portugal), with electrical stunning followed by exsanguination. The hot carcass weight (HCW) was measured in order to calculate carcass yield. Perirenal and mesenteric fat depot was removed and weighed. Longissimus lumborum muscle was collected from the right carcass side between the third and fifth lumbar vertebras, minced, immediately vacuum packed and stored at $-20{ }^{\circ} \mathrm{C}$, to assess meat quality, and at $-80^{\circ} \mathrm{C}$, for meat oxidative stability determinations.

At $24 \mathrm{~h}$ post mortem, backfat thickness was measured in the left side of carcass at the last rib position (P2) (the most representative location), last lumbar vertebra (L6) and second sacral vertebra (S2), using a calibrated engineering calliper (150 mm Electronic Digital Vernier Calliper CE ROHS) as described by Frederick [21]. The loin was excised from the left side of carcass, between the last cervical and L6 lumbar vertebras, weighted and sliced into 2.5-cm-thick chops for sensory evaluation, shear force measurements, color and drip loss determinations. Chops were vacuum packed, frozen and stored at $-20^{\circ} \mathrm{C}$ until sensory analysis and shear force measurements.

\subsection{Microalga and Experimental Diets Analyses}

Experimental diets were collected three times during the entire trial. The Association of Official Analytical Chemists (AOAC) [22] methods were used to determine the proximal composition of C. vulgaris microalga and experimental diets. Samples were dried at $103{ }^{\circ} \mathrm{C}$ until reach constant weight to determine dry matter (DM). Crude protein of samples was calculated through the determination of the nitrogen content $(\mathrm{N})$ by the Kjeldahl method using the factor $6.25 \times \mathrm{N}$ following the method 954.01 [22]. Ash and starch contents of samples were determined according to the method 942.05 [22] and Clegg [23] procedure, respectively. Crude fat of samples was determined after automatic Soxhlet extraction with petroleum ether (Gerhardt Analytical Systems, Königswinter, Germany). Crude fiber, acid detergent fiber (ADF) and neutral detergent fiber (NDF) were determined by the method 989.03 [22]. Metabolizable energy (ME) was calculated according to Noblet et al. [24].

The amino acid composition of $C$. vulgaris and experimental diets was determined according to the method 994.12 [25] and quantified by High-Performance Liquid Chromatography (HPLC) (Agilent 1100, Agilent Technologies, Avondale, PA, USA), as described by Henderson et al. [26]. The fatty acid methyl esters (FAME) profile of $C$. vulgaris and experimental diets were analyzed by one-step extraction and acid transesterification, followed by gas chromatography using heneicosaenoic acid (21:0) methyl ester as the internal standard [27].

The diterpene profile of $C$. vulgaris and experimental diets was analyzed by direct saponification, using a single $n$-hexane extraction followed by HPLC analysis [28]. The determination of pigments in C. vulgaris and experimental diets was performed according to Teimouri et al. [29], with slight modifications as described in Pestana et al. [30]. The quantification of pigments in C. vulgaris and experimental diet samples were performed according to Hynstova et al. [31].

\subsection{Meat Quality Traits}

The $\mathrm{pH}$ and temperature of longissimus lumborum muscle were measured in the right carcass side at $45 \mathrm{~min}$ and $24 \mathrm{~h}$ post mortem using a $\mathrm{pH}$ meter equipped with a penetrating electrode (HI8424, Hanna Instruments, Woonsocket, RI, USA). Meat color was measured on the cut surface of longissimus lumborum section, $24 \mathrm{~h}$ post mortem, using a colorimeter (Minolta CR-400, Konica Minolta, Tokyo, Japan) with the illuminant D65, at an observer angle of $2^{\circ}$ and $1 \mathrm{~cm}$ diameter of measurement area. 
Three measurements on different locations per sample were recorded following the CIE color convention $\mathrm{L}^{*}$ (lightness), $\mathrm{a}^{*}$ (redness) and $\mathrm{b}^{*}$ (yellowness) system after $1 \mathrm{~h}$ of blooming at $4{ }^{\circ} \mathrm{C}$ [32].

Drip loss of fresh longissimus lumborum muscle was performed according to Hope-Jones et al. [33]. The amount of drip measured between $24 \mathrm{~h}$ and $144 \mathrm{~h}$ post mortem was expressed as a percentage of the initial mass of the sample, and calculated through the difference between the sample mass at the beginning and end of the storage period.

\subsection{Cooking Loss and Shear Force Measurements}

Meat cooking loss and shear force were determined according to the procedure adapted from Honikel [34] and Oillic et al. [35]. Frozen meat samples were thawed at $2 \pm 1{ }^{\circ} \mathrm{C}$ overnight, weighed and cooked in a water bath at $80 \pm 0.5^{\circ} \mathrm{C}$ until reaching the temperature of $75 \pm 0.5^{\circ} \mathrm{C}$ in the geometric center, using an internal thermocouple (Thermometer Omega RDXL4SD, Manchester, NH, USA). The samples were cooled for $20 \mathrm{~h}\left(2 \pm 1^{\circ} \mathrm{C}\right)$, weighed in order to calculate the cooking loss, and longitudinally cut in the fiber axis parallel to muscle fiber direction into 8 to 12 cores, with a $1-\mathrm{cm}^{2} \mathrm{cross}$-section area for shear force determinations. Cooking loss, expressed as percentage, was calculated by the difference of the weights before and after cooking divided by the initial weight of the sample [36].

The Warner-Bratzler shear force (WBSF) was measured in a texture analyzer (TA-XT Plus texture analyzer; Stable Micro Systems, Surrey, UK) with a Warner-Bratzler shear device with a 30-kg compression load cell, trigger force was $25 \mathrm{~g}$ and crosshead speed during pre-test, test and post-test set were 5.0, 2.0, and $10.0 \mathrm{~mm} / \mathrm{s}$, respectively. Force and distance were recorded at 200 points/s and analyzed with the Version 6.1.16 of Exponent software (Stable Micro Systems, Surrey, UK). The value of the peak shear force of cores from each sample was determined and averaged to obtain a single WBSF value per sample.

\subsection{Trained Sensory Panel Analysis}

A trained sensory panel with five sessions was used to evaluate meat sensory characteristics. The eleven panelists were selected and trained according to Cross et al. [37]. For each session, meat samples were thawed at $2 \pm 1{ }^{\circ} \mathrm{C}$ overnight and cooked at $170 \pm 5{ }^{\circ} \mathrm{C}$ in a Ceramic Contact Grill $1.6 \mathrm{~kW}$ (UNOX Catering Equipment, Padova, Italy) with an internal thermocouple in each sample (Thermometer Omega RDXL4SD, Manchester, NH, USA) until reached $71{ }^{\circ} \mathrm{C}$ in the geometric center. After $10 \mathrm{~min}$ of stabilization at $40{ }^{\circ} \mathrm{C}$, the sample was trimmed of the six external surfaces, included connective tissue, cut into $1 \times 1 \times 1 \mathrm{~cm}$ subsamples and maintained, on individual covered plates, in an incubator at $40{ }^{\circ} \mathrm{C}$ until tasting (no longer than $30 \mathrm{~min}$ ) [38]. Samples were randomly distributed across sections and the attributes evaluated were juiciness, tenderness, flavor intensity, off-flavor, flavor acceptability, and overall acceptability. These attributes were classified on a grading scale from 1 (extremely dry, tough, soft, weak, or unacceptable) to 8 (extremely juicy, tender, strong, positive and positive), with the exception of off-flavor quantified from 0 (absence) or 1 (presence) [39].

\subsection{Determination of Total Cholesterol and Diterpene Profile in Meat}

The simultaneous quantification of total cholesterol, $\beta$-carotene and vitamin E homologues (tocopherols and tocotrienols) in longissimus lumborum samples was performed, in duplicate, as previously described by Prates et al. [28]. Muscle samples were submitted to a saponification reaction in a water bath at $80{ }^{\circ} \mathrm{C}$ for $15 \mathrm{~min}$ under agitation. Afterwards, the diterpenes were extracted with $n$-hexane and analyzed by HPLC system (Agilent 1100 Series, Agilent Technologies Inc., Palo Alto, CA, USA), using a normal-phase silica column (Zorbax RX-Sil, $250 \mathrm{~mm} \times 4.6 \mathrm{~mm}$ i.d., $5 \mu \mathrm{m}$ particle size, Agilent Technologies Inc, Santa Clara, CA, USA). The HPLC analysis was performed using UV-visible photodiode array detector for cholesterol $(\lambda=202 \mathrm{~nm})$ and $\beta$-carotene $(\lambda=450 \mathrm{~nm})$ coupled to fluorescence detector for tocopherols and tocotrienols (excitation $\lambda=295 \mathrm{~nm}$ and emission $\lambda=325 \mathrm{~nm}$ ). Standard curves of peak area versus concentration was used to quantify total cholesterol, $\beta$-carotene and vitamin $\mathrm{E}$ homologues contents in meat samples. 


\subsection{Determination of Pigments in Meat}

The contents of chlorophyll $a$, chlorophyll $b$ and total carotenoids were measured according to the procedure of Teimouri et al. [29] modified by Pestana et al. [30]. One g of each sample was incubated overnight with $10 \mathrm{~mL}$ of acetone (Merck KGaA, 249 Darmstadt, Germany) under agitation at room temperature in absence of light. Then, samples were centrifuged at $3345 \times g$ for $5 \mathrm{~min}$ and the absorbance was measured in the supernatants using a UV-VIS spectrophotometer (Ultrospec 3100 pro, Amersham Biosciences, Little Chalfont, UK). The results were calculated according to Hynstova et al. [31], as described above for C. vulgaris microalga and experimental diets.

\subsection{Determination of Total Lipid Content and Fatty Acid Composition}

Longissimus lumborum muscle samples were lyophilized $\left(-60^{\circ} \mathrm{C}\right.$ and $\left.2.0 \mathrm{hPa}\right)$ using a lyophilizator Edwards Modulyo (Edwards High Vacuum International, Crawley, UK) for total lipids determination according to Folch et al. [40]. Total lipid content was determined gravimetrically, in duplicate, by weighing the fat residue obtained after solvent evaporation. Then, the fat residue was re-suspended in dry toluene and submitted to sequential alkaline and acid transesterification procedure at $50{ }^{\circ} \mathrm{C}$ for 30 and $10 \mathrm{~min}$, respectively, to convert fatty acids into FAME [41]. FAME were separated through gas chromatography (HP7890A Hewlett-Packard, Avondale, PA, USA) comprising a Supelcowax ${ }^{\circledR} 10$ capillary column (30 $\mathrm{m} \times 0.20 \mathrm{~mm}$ internal diameter, $0.20 \mu \mathrm{m}$ film thickness; Supelco, Bellefonte, PA, USA) and a flame ionization detector as described by Madeira et al. [42]. For FAME identification, a reference standard (FAME mix 37 components, Supelco Inc, Bellefonte, PA, USA) was used and confirmed by gas chromatography with a mass spectrometry detector using a GC-MS QP2010-Plus (Shimadzu, Kyoto, Japan). FAME were quantified by the internal standard method using heneicosanoic acid (21:0) methyl ester as internal standard. The fatty acids identified were expressed as percentage of total fatty acids.

\subsection{Determination of Meat Lipid Oxidation}

The extent of meat lipid oxidation was evaluated at day 0,4 and 8 post mortem (storage at $4{ }^{\circ} \mathrm{C}$ ), by quantifying thiobarbituric acid reactive substances (TBARS), following the spectrophotometric method described by Grau et al. [43]. TBARS values were calculated, in duplicate, from a standard curve constructed with 1,1,3,3-tetraethoxypropane (Fluka, Neu Ulm, Germany), as a precursor of malonaldehyde, and the results were presented as $\mathrm{mg}$ of malonaldehyde per $\mathrm{kg}$ of meat [42]. In addition, lipid peroxidation levels in meat were also measured by the concentration of TBARS, after chemical oxidation through a ferrous-hydrogen peroxide system, as described by Mercier et al. [44]. The TBARS were quantified after $0,30,120$, and $300 \mathrm{~min}$ of oxidation induction following the method described above.

\subsection{Statistical Analysis}

All data were checked for normal distribution and variance homogeneity. Data were analyzed by analysis of variance using the PROC GLM of SAS software package (version 9.4; SAS Institute Inc., Cary, NC, USA) and measurements over time analyzed with PROC MIXED of SAS. The statistical model considered the dietary treatment the fixed effect and the pig the experimental unit. Least square means for multiple comparisons were generated using the PDIFF option adjusted with the Tukey-Kramer method. The significance level was set at $p<0.05$.

\section{Results and Discussion}

\subsection{Feed Intake, Growth Performance and Carcass Characteristics of Pigs}

Data on feed intake, growth performance and carcass traits of finishing pigs are shown in Table 3. Growth performance variables had no significant differences among animals fed with different 
experimental diets $(p>0.05)$. The average values of ADG, ADFI, and FCR were $1.02 \mathrm{~kg}, 2.62 \mathrm{~kg}$, and $2.59 \mathrm{~kg}$, respectively. No significant differences in carcass characteristics were obtained among the experimental groups $(p>0.05)$, with the exception of perirenal fat $(p=0.026)$. The control group displayed a higher value of perirenal fat than the group fed with the C. vulgaris diet $(+34 \%)$.

Table 3. Effect of experimental diets on growth performance and carcass characteristics of pigs.

\begin{tabular}{|c|c|c|c|c|c|c|}
\hline Item & Control & $\mathrm{CV}$ & $\mathrm{CV}+\mathrm{R}$ & $\mathrm{CV}+\mathrm{M}$ & SEM & $p$-Value \\
\hline \multicolumn{7}{|c|}{ Growth performance } \\
\hline Initial weight, $\mathrm{kg}$ & 62.8 & 56.1 & 58.4 & 59.4 & 1.79 & 0.075 \\
\hline Final weight, kg & 101 & 101 & 101 & 101 & 0.643 & 0.927 \\
\hline ADFI, $\mathrm{kg}$ & 2.56 & 2.67 & 2.65 & 2.60 & 0.052 & 0.409 \\
\hline $\mathrm{ADG}, \mathrm{kg}$ & 0.959 & 1.08 & 1.01 & 1.04 & 0.037 & 0.141 \\
\hline FCR & 2.69 & 2.49 & 2.63 & 2.55 & 0.079 & 0.286 \\
\hline $\mathrm{G}: \mathrm{F}, \mathrm{kg} / \mathrm{kg}$ & 0.374 & 0.404 & 0.382 & 0.398 & 0.011 & 0.244 \\
\hline \multicolumn{7}{|c|}{ Carcass characteristics } \\
\hline $\mathrm{HCW}, \mathrm{kg}$ & 80.1 & 79.5 & 79.3 & 78.9 & 0.735 & 0.703 \\
\hline Carcass yield, \% & 77.4 & 77.1 & 76.9 & 76.8 & 0.430 & 0.749 \\
\hline Perirenal fat, kg & $0.897^{b}$ & $0.666^{\mathrm{a}}$ & $0.806^{a b}$ & $0.711^{\mathrm{ab}}$ & 0.055 & 0.026 \\
\hline Mesenteric fat, $\mathrm{kg}$ & 0.525 & 0.530 & 0.572 & 0.583 & 0.024 & 0.231 \\
\hline $\mathrm{P}_{2}$ backfat thickness, $\mathrm{mm}$ & 6.38 & 5.54 & 7.17 & 6.40 & 0.633 & 0.359 \\
\hline L6 backfat thickness, $\mathrm{mm}$ & 9.33 & 10.1 & 10.8 & 9.64 & 0.758 & 0.535 \\
\hline $\mathrm{S} 2$ backfat thickness, $\mathrm{mm}$ & 4.98 & 5.22 & 5.42 & 5.77 & 0.737 & 0.891 \\
\hline Loin weight, $\mathrm{kg}$ & 2.14 & 2.11 & 2.10 & 2.18 & 0.066 & 0.850 \\
\hline Drip loss $\%{ }^{1}$ & 5.82 & 5.63 & 7.27 & 6.51 & 0.460 & 0.065 \\
\hline
\end{tabular}

Experimental diets: Control-corn-soybean basal diet; $\mathrm{CV}$-basal diet plus $5 \% \mathrm{C}$. vulgaris; $\mathrm{CV}+\mathrm{R}$-basal diet plus $5 \%$ C. vulgaris $+0.005 \%$ Rovabio ${ }^{\circledR}$ Excel AP; CV + M-basal diet plus $5 \%$ C. vulgaris $+0.01 \%$ mix of 4 CAZymes. SEM-standard error of the mean; ADFI-average daily feed intake; ADG - average daily weight gain; FCR-feed conversion ratio; G:F-gain-feed ratio; $\mathrm{HCW}$-hot carcass weight; $\mathrm{P}_{2}$-at the last rib position; L6-at the last lumbar vertebra; S2-at the second sacral vertebra. ${ }^{1}$ Measured as the amount of drip between $24 \mathrm{~h}$ and $144 \mathrm{~h}$ post mortem.

$\mathrm{a}, \mathrm{b}$ Values within a row with different superscripts differ significantly at $p<0.05$.

We assessed, for the first time, the impact of a high dietary level ( $>2 \%$ in diet) of $C$. vulgaris, individually and combined with two exogenous CAZymes, on pig performance. In fact, some studies reported the use of $C$. vulgaris in pig diets but at much lower levels (1\% in the diet or lower), compared with the 5\% incorporated in the current trial [45-47]. Baňoch et al. [46] investigated the effect of a very low level $(0.0002 \%)$ of incorporation of $C$. vulgaris in female pigs, with an initial weight of $30 \mathrm{~kg}$, and found no significant differences in ADG, HCW, lean muscle thickness and backfat thickness. Later, Furbeyre and colleagues [47] showed no significant effects on ADG, ADFI, and FCR, by using $1 \%$ of $C$. vulgaris in weaned piglet diets, with an initial weight of $9.1 \mathrm{~kg}$, during 14 days. In another study, the same authors assessed the effect of oral supplementation with C. vulgaris ( $385 \mathrm{mg} / \mathrm{kg} \mathrm{BW}$ ) on growth and digestive health of weaning piglets and also found no significant changes in ADG, ADFI and G:F [48]. In addition, a study conducted in growing pigs, with an initial weight of $26.6 \mathrm{~kg}$ and C. vulgaris incorporation of $0.1 \%$ and $0.2 \%$ in the diet, described an increase of ADG with the lower dietary level without significant variations in ADFI and G:F [45]. In the present study, no significant effects on zootechnical parameters and carcass characteristics were obtained, which indicates that dietary incorporation of $5 \%$ C. vulgaris does not compromise the productive parameters of finishing pigs. Moreover, the dietary supplementation with exogenous carbohydrases, aiming at improving C. vulgaris digestibility by finishing pigs, does not seem to be necessary at this high incorporation level.

\subsection{Pork Quality Traits and Sensory Evaluation}

Data concerning the effect of experimental diets on quality traits of longissimus lumborum muscle from finishing pigs are presented on Table 4. Experimental treatments had no significant effect on temperature $45 \mathrm{~min}$ post mortem, $\mathrm{pH} 45 \mathrm{~min}$ and $24 \mathrm{~h}$ post mortem, color parameters, WBSF and cooking loss $(p>0.05)$. Table 5 summarizes the trained panel scores obtained for pork. No significant 
differences were obtained among experimental diets for the several items evaluated by the trained sensory panel $(p>0.05)$.

Table 4. Effect of experimental diets on meat quality traits of longissimus lumborum muscle from pigs.

\begin{tabular}{|c|c|c|c|c|c|c|}
\hline Item & Control & $\mathrm{CV}$ & $C V+R$ & $\mathrm{CV}+\mathrm{M}$ & SEM & $p$-Value \\
\hline \multicolumn{7}{|c|}{ Temperature, ${ }^{\circ} \mathrm{C}$} \\
\hline $45 \mathrm{~min}$ & 39.9 & 39.8 & 39.7 & 40.0 & 0.246 & 0.911 \\
\hline \multicolumn{7}{|c|}{$\mathrm{pH}$} \\
\hline $45 \mathrm{~min}$ & 6.11 & 6.34 & 6.12 & 6.28 & 0.109 & 0.351 \\
\hline $24 \mathrm{~h}$ & 5.49 & 5.54 & 5.50 & 5.51 & 0.016 & 0.260 \\
\hline \multicolumn{7}{|c|}{ Color measurements } \\
\hline Lightness $\left(\mathrm{L}^{*}\right)$ & 57.0 & 56.5 & 57.9 & 56.9 & 0.976 & 0.791 \\
\hline Redness $\left(\mathrm{a}^{*}\right)$ & 6.50 & 5.68 & 6.28 & 6.39 & 0.600 & 0.770 \\
\hline Yellowness $\left(b^{*}\right)$ & 7.26 & 6.46 & 7.24 & 7.07 & 0.526 & 0.679 \\
\hline \multicolumn{7}{|c|}{ Other traits } \\
\hline WBSF, kg & 6.92 & 7.17 & 6.44 & 6.95 & 0.373 & 0.574 \\
\hline Cooking loss, $\%$ & 30.8 & 30.7 & 31.0 & 30.1 & 0.605 & 0.740 \\
\hline
\end{tabular}

Experimental diets: Control-corn-soybean basal diet; CV-basal diet plus $5 \%$. vulgaris; $C V+R$-basal diet plus $5 \%$ C. vulgaris $+0.005 \%$ Rovabio ${ }^{\circledR}$ Excel AP; CV + M-basal diet plus $5 \%$ C. vulgaris $+0.01 \%$ mix of 4 CAZymes. SEM-standard error of the mean. * Color parameters CIE L* $\mathrm{a}^{*} \mathrm{~b}^{*}$ system. WBSF-Warner-Bratzler shear force.

Table 5. Effect of experimental diets on sensory panel scores of longissimus lumborum muscle from pigs.

\begin{tabular}{ccccccc}
\hline Item & Control & $\mathbf{C V}$ & $\mathbf{C V}+\mathbf{R}$ & $\mathbf{C V}+\mathbf{M}$ & SEM & $p$-Value \\
\hline Tenderness & 4.45 & 4.61 & 4.57 & 4.54 & 0.117 & 0.788 \\
Juiciness & 3.72 & 3.85 & 3.74 & 3.84 & 0.111 & 0.760 \\
Flavor & 4.09 & 4.20 & 4.29 & 4.20 & 0.109 & 0.649 \\
Off-flavor & 0.061 & 0.111 & 0.171 & 0.131 & 0.029 & 0.064 \\
Flavor acceptability & 5.55 & 5.29 & 5.36 & 5.32 & 0.104 & 0.260 \\
Overall acceptability & 5.23 & 5.22 & 5.13 & 5.10 & 0.101 & 0.756 \\
\hline
\end{tabular}

Experimental diets: Control-corn-soybean basal diet; CV-basal diet plus $5 \%$ C. vulgaris; $\mathrm{CV}+\mathrm{R}$-basal diet plus $5 \%$ C. vulgaris $+0.005 \%$ Rovabio ${ }^{\circledR}$ Excel AP; CV + M-basal diet plus $5 \%$ C. vulgaris $+0.01 \%$ mix of 4 CAZymes. SEM-standard error of the mean.

Similar results for meat quality traits were reported by Baňoch et al. [46], who found that a $0.0002 \%$ level of incorporation of $C$. vulgaris in pig diets had no significant effect on color, $\mathrm{pH}$, cooking loss and drip loss of pork. Here, the dietary incorporation of 5\% C. vulgaris did not change pork quality traits and sensory parameters, which is very important for the consumer acceptance of this meat. By contrast, Oh et al. [49] observed an increase of $\mathrm{b}^{*}, \mathrm{pH}$ and shear force in breast meat, and an increase of $\mathrm{L}^{*}$ and $\mathrm{b}^{*}$ in leg meat, of male Pekin ducks fed with $0.1-0.2 \%$ C. vulgaris during 42 days. Therefore, pork quality traits seem to be less sensitive to the dietary inclusion of $C$. vulgaris than poultry meat characteristics, although both are meats-derived from monogastric animals. Finally, it was also indicated here that the dietary use of CAZyme mixtures does not affect pork quality characteristics.

\subsection{Vitamin E Profile and Pigments of Pork}

The effect of experimental diets on vitamin E profile and pigments of longissimus lumborum muscle from finishing pigs is shown in Table 6. Experimental diets did not contribute to significant differences on the diterpene profile $(p>0.05)$. Regarding pigments analysis, $\beta$-carotene was not detected in any group fed with experimental diets, and there were no significant differences among experimental groups for chlorophyll $a$, chlorophyll $b$ and total chlorophylls $(p>0.05)$. However, for total carotenoids, there were significant differences between animals fed Control diet and pigs fed C. vulgaris diets $(p=0.042)$, with approximately the double content of meat carotenoids in animals fed with the microalga. This could be explained by the much higher level of carotenoids in $C$. vulgaris diets that in the control diet (about nine times). In addition, there was also significant differences among groups fed with experimental diets for total chlorophylls and carotenoids $(p=0.038)$, being the sum 
two-fold higher in the group fed with $\mathrm{CV}+\mathrm{R}$ diet compared with the control group; pork from animals fed with $\mathrm{CV}$ and $\mathrm{CV}+\mathrm{M}$ diets had intermediate values of total pigments.

Table 6. Effect of experimental diets on vitamin E profile and pigments of longissimus lumborum muscle from pigs.

\begin{tabular}{|c|c|c|c|c|c|c|}
\hline Item & Control & CV & $\begin{array}{c}\mathrm{CV}+ \\
\mathrm{R}\end{array}$ & $\begin{array}{c}\mathrm{CV}+ \\
\mathrm{M}\end{array}$ & SEM & $p$-Value \\
\hline \multicolumn{7}{|c|}{ Diterpene profile, $\mu \mathrm{g} / 100 \mathrm{~g}$} \\
\hline$\alpha$-Tocopherol & 95.4 & 73.6 & 74.9 & 79.4 & 6.2 & 0.062 \\
\hline$\gamma$-Tocopherol & 3.5 & 3.7 & 3.5 & 3.2 & 0.2 & 0.441 \\
\hline$\gamma$-Tocotrienol & 10.2 & 9.0 & 10.4 & 8.2 & 1.9 & 0.821 \\
\hline \multicolumn{7}{|c|}{ Pigments, $\mu \mathrm{g} / 100 \mathrm{~g}$} \\
\hline$\beta$-Carotene & nd & nd & nd & nd & - & - \\
\hline Chlorophyll a & 14.7 & 23.9 & 31.3 & 28.0 & 4.75 & 0.094 \\
\hline Chlorophyll b & 27.7 & 47.2 & 56.9 & 54.7 & 9.00 & 0.109 \\
\hline Total chlorophylls & 42.4 & 71.2 & 88.1 & 82.8 & 13.7 & 0.103 \\
\hline Total carotenoids & $7.18^{\mathrm{a}}$ & $16.4^{\mathrm{b}}$ & $16.4^{\mathrm{b}}$ & $15.1^{\mathrm{b}}$ & 2.55 & 0.042 \\
\hline Total chlorophylls and carotenoids & $49.6^{\mathrm{a}}$ & $87.6^{\mathrm{ab}}$ & $104^{b}$ & $97.9^{a b}$ & 13.9 & 0.038 \\
\hline
\end{tabular}

Experimental diets: Control-corn-soybean basal diet; CV-basal diet plus $5 \%$ C. vulgaris; $\mathrm{CV}+\mathrm{R}$-basal diet plus $5 \%$ C. vulgaris $+0.005 \%$ Rovabio $^{\circledR}$ Excel AP; CV + M-basal diet plus $5 \%$ C. vulgaris $+0.01 \%$ mix of 4 CAZymes. SEM-standard error of the mean. nd-not detected. ${ }^{a}, b$ Values within a row with different superscripts differ significantly at $p<0.05$.

$\alpha$-Tocopherol was the major diterpene in all groups fed with the experimental diets, while the other vitamin $E$ homologues were present at lower concentrations. Concerning pigments, $\beta$-carotene (a pro-vitamin A) was not detected in pork, which could indicate that $\beta$-carotene in the diet is quickly metabolized into vitamin A [50], as animals cannot synthesize carotenoids by themselves [51]. C. vulgaris, due to the photosynthetic pathway, is also rich in pigments, such as chlorophylls and carotenoids. Despite the fact that $\beta$-carotene was not detected, the inclusion of $5 \%$ C. vulgaris in pig diets, combined or not with the two exogenous CAZyme mixtures, improved the carotenoid content of pork, thus providing further nutritional benefits for consumers. Total carotenoids were strongly in conformity with diet composition. Similar results were reported by Lemahieu et al. [52], who studied the effect of dietary supplementation of laying hens with different $n-3$ rich autotrophic microalgae, including Chlorella, on meat carotenoids. These authors reported that the transference of carotenoids from the microalgae to the meat provides an additional value for microalgae supplementation.

\subsection{Total Lipids, Cholesterol and Fatty Acid Composition of Pork}

Table 7 shows the effect of dietary inclusion of $C$. vulgaris, alone or combined with exogenous CAZymes, on total lipids, cholesterol, and fatty acid composition of longissimus lumborum muscle from pigs. Pork contents of total lipids and cholesterol were not affected by experimental diets $(p>0.05)$. In addition, experimental diets promoted only significant differences in the percentage of some minor fatty acids ( $<1 \%$ of total fatty acids). Control group had a higher percentage of the saturated fatty acid 10:0 relative to $C V$ and $C V+M$ groups $(p=0.013)$. In contrast, the percentages of the monounsaturated fatty acid $14: 1 c 9$ and $n-3$ fatty acids $18: 3 n-3,18: 4 n-3,20: 3 n-3,20: 5 n-3,22: 5 n-3$, and 22:6n-3 were generally lower in the Control group relative to the $C$. vulgaris groups. Among microalga experimental groups, the group fed with $\mathrm{CV}+\mathrm{M}$ usually had the highest percentage of these unsaturated fatty acids. In fact, both percentages of DPA and DHA increased 1.6-fold for CV + M diet comparing with the control diet. Contrarily, $\alpha$-linolenic acid had higher percentages in all microalga-fed animals relative to the control group $(+48 \%)$. 
Table 7. Effect of experimental diets on total lipid content, total cholesterol and fatty acid (FA) composition of longissimus lumborum muscle from pigs.

\begin{tabular}{|c|c|c|c|c|c|c|}
\hline Item & Control & $\mathrm{CV}$ & $\mathrm{CV}+\mathrm{R}$ & $\mathrm{CV}+\mathrm{M}$ & SEM & $p$-Value \\
\hline Total lipids, g/100 g & 1.18 & 1.03 & 1.05 & 0.933 & 0.073 & 0.141 \\
\hline Cholesterol, $\mathrm{mg} / \mathrm{g}$ & 0.363 & 0.363 & 0.361 & 0.367 & 0.015 & 0.993 \\
\hline \multicolumn{7}{|c|}{ FA composition, g/100 g FA } \\
\hline 10:0 & $0.053^{b}$ & $0.023^{a}$ & $0.042^{a b}$ & $0.023^{a}$ & 0.007 & 0.013 \\
\hline $12: 0$ & 0.056 & 0.045 & 0.053 & 0.051 & 0.006 & 0.536 \\
\hline $14: 0$ & 1.05 & 0.952 & 0.994 & 0.904 & 0.045 & 0.126 \\
\hline $14: 1 c 9$ & $0.034^{\mathrm{a}}$ & $0.062^{a b}$ & $0.064^{\mathrm{ab}}$ & $0.068^{b}$ & 0.008 & 0.021 \\
\hline 15:0 & 0.081 & 0.072 & 0.067 & 0.069 & 0.007 & 0.519 \\
\hline DMA 16:0 & 0.089 & 0.047 & 0.054 & 0.140 & 0.029 & 0.107 \\
\hline 16:0 & 23.4 & 22.8 & 23.2 & 22.5 & 0.279 & 0.119 \\
\hline $16: 1 c 7$ & 0.335 & 0.352 & 0.338 & 0.388 & 0.015 & 0.065 \\
\hline $16: 1 c 9$ & 2.94 & 2.67 & 2.79 & 2.42 & 0.131 & 0.054 \\
\hline 17:0 & 0.432 & 0.435 & 0.417 & 0.460 & 0.038 & 0.882 \\
\hline $17: 1 c 9$ & 0.340 & 0.369 & 0.363 & 0.334 & 0.023 & 0.647 \\
\hline DMA 18:0 & 0.045 & 0.019 & 0.067 & 0.076 & 0.032 & 0.597 \\
\hline DMA 18:1 & 0.023 & 0.006 & 0.034 & 0.039 & 0.020 & 0.637 \\
\hline 18:0 & 11.9 & 11.6 & 11.9 & 12.2 & 0.373 & 0.698 \\
\hline $18: 1 c 9$ & 37.3 & 36.1 & 36.7 & 34.8 & 0.933 & 0.270 \\
\hline 18:1c11 & 3.99 & 3.94 & 3.91 & 3.79 & 0.072 & 0.260 \\
\hline $18: 2 n-6$ & 11.8 & 13.4 & 12.4 & 13.9 & 0.846 & 0.291 \\
\hline $18: 2 t 9 t 12$ & 0.039 & 0.034 & 0.026 & 0.032 & 0.006 & 0.494 \\
\hline $18: 3 n-6$ & 0.121 & 0.129 & 0.123 & 0.133 & 0.014 & 0.934 \\
\hline $18: 3 n-3$ & $0.279^{a}$ & $0.408^{b}$ & $0.377^{b}$ & $0.381^{b}$ & 0.020 & $>0.001$ \\
\hline $18: 4 n-3$ & $0.027^{a}$ & $0.050^{b}$ & $0.041^{a b}$ & $0.058^{b}$ & 0.006 & 0.004 \\
\hline 20:0 & 0.167 & 0.154 & 0.161 & 0.171 & 0.007 & 0.422 \\
\hline $20: 1 c 11$ & 0.604 & 0.593 & 0.594 & 0.595 & 0.033 & 0.996 \\
\hline $20: 2 n-6$ & 0.341 & 0.358 & 0.326 & 0.336 & 0.018 & 0.675 \\
\hline $20: 3 n-6$ & 0.362 & 0.415 & 0.383 & 0.457 & 0.035 & 0.270 \\
\hline $20: 4 n-6$ & 2.30 & 2.72 & 2.40 & 2.93 & 0.280 & 0.368 \\
\hline $20: 3 n-3$ & $0.056^{\mathrm{a}}$ & $0.080^{a b}$ & $0.089^{b}$ & $0.092^{b}$ & 0.008 & 0.008 \\
\hline $20: 5 n-3$ & $0.064^{\mathrm{a}}$ & $0.119^{b}$ & $0.114^{b}$ & $0.112^{b}$ & 0.015 & 0.042 \\
\hline $22: 0$ & 0.068 & 0.070 & 0.069 & 0.088 & 0.008 & 0.240 \\
\hline $22: 1 n-9$ & 0.047 & 0.049 & 0.055 & 0.043 & 0.008 & 0.740 \\
\hline $22: 5 n-3$ & $0.266^{\mathrm{a}}$ & $0.385^{a b}$ & $0.356^{\mathrm{ab}}$ & $0.428^{b}$ & 0.040 & 0.036 \\
\hline $22: 6 n-3$ & $0.241^{\mathrm{a}}$ & $0.328^{a b}$ & $0.342^{a b}$ & $0.393^{b}$ & 0.038 & 0.035 \\
\hline 23:0 & 0.162 & 0.189 & 0.170 & 0.211 & 0.021 & 0.366 \\
\hline Others & 0.946 & 1.03 & 1.02 & 1.35 & 0.227 & 0.615 \\
\hline \multicolumn{7}{|c|}{ Partial sums of FA, g/100 g FA } \\
\hline SFA & 37.4 & 36.4 & 37.1 & 36.7 & 0.534 & 0.564 \\
\hline MUFA & 45.6 & 44.2 & 44.8 & 42.4 & 1.09 & 0.213 \\
\hline PUFA & 15.9 & 18.4 & 17.0 & 19.3 & 1.25 & 0.243 \\
\hline n-6 PUFA & 14.9 & 17.0 & 15.6 & 17.8 & 1.17 & 0.306 \\
\hline n-3 PUFA & $0.932^{\mathrm{a}}$ & $1.37^{\mathrm{b}}$ & $1.32^{b}$ & $1.46^{\mathrm{b}}$ & 0.093 & 0.001 \\
\hline \multicolumn{7}{|c|}{ Ratios of FA } \\
\hline PUFA:SFA & 0.427 & 0.508 & 0.461 & 0.530 & 0.038 & 0.232 \\
\hline$n-6: n-3$ & $16.1^{\mathrm{b}}$ & $12.3^{\mathrm{a}}$ & $11.9^{\mathrm{a}}$ & $12.3^{\mathrm{a}}$ & 0.395 & $<0.001$ \\
\hline
\end{tabular}

Experimental diets: Control-corn-soybean basal diet; CV-basal diet plus $5 \%$ C. vulgaris; CV + R -basal diet plus $5 \%$ C. vulgaris $+0.005 \%$ Rovabio ${ }^{\circledR}$ Excel AP; CV $+\mathrm{M}$ - basal diet plus $5 \%$ C. vulgaris $+0.01 \%$ mix of 4 CAZymes. SEM-standard error of the mean; FA-fatty acids; DMA-dimethylacetal; SFA-saturated fatty acids; MUFA-monounsaturated fatty acids; PUFA-polyunsaturated fatty acids. SFA = Sum of (10:0, 12:0, 14:0, 15:0, 16:0, 17:0, 18:0, 20:0, 22:0 and 23:0). MUFA = Sum of $(14: 1 c 9,16: 1 c 7,16: 1 c 9,17: 1 c 9,18: 1 c 9,18: 1 c 11,20: 1 c 11$ and 22:1n-9). PUFA = Sum of (18:2n-6, 18:3n-6, 18:2t9t12, 18:3n-3, 18:4n-3, 20:2n-6, 20:3n-6, 20:4n-6, 20:3n-3, 20:5n-3, 22:5n-3 and 22:6n-3). $n-3$ PUFA = Sum of (18:3n-3, 18:4n-3, 20:3n-3, 20:5n-3, 22:5n-3 and 22:6n-3). $n-6$ PUFA = Sum of (18:2n-6, $18: 3 n-6,20: 2 n-6,20: 3 n-6$, and 20:4n-6). ${ }^{\text {a, b }}$ Values within a row with different superscripts differ significantly at $p<0.05$. 
Regarding partial sums of fatty acids, total $n-3$ PUFA in pork had a significant increase of approximately $50 \%$ in microalga-fed groups comparing with the control group $(p=0.001)$. This increase reflects the individual effects of the predominant $n$-3 PUFA ( $\alpha$-linolenic acid, DPA, and DHA). The other partial sums of fatty acids, as well as the PUFA:SFA ratio, were not affected by the dietary treatment. However, the $n-6: n-3$ ratio decreased in all microalga-fed groups, in an extension of $24 \%$, comparing with the Control group $(p<0.001)$. Feeding pigs with $5 \%$ of $C$. vulgaris increased the $n-3$ PUFA content in pork, which showed a correspondence between dietary and deposited $n-3$ PUFA in muscle. This finding reveals the ability of muscle to capture the precursor $\alpha$-linolenic acid from $C$. vulgaris diets and its ability to convert it into $n$ - 3 PUFA derivatives. The $n$ - 3 long-chain PUFA ( $n$ - 3 LC-PUFA), such as EPA and DHA, are of great interest for human diets due to their recognized positive effects, which includes anti-atherogenic, anti-thrombotic, and anti-inflammatory properties [53]. In fact, a well-balanced fatty acids intake is crucial to reduce the risk of cardiovascular and related diseases [54]. However, the intake of $n$-3 PUFA remains relatively low in human populations. In Europe, $n-3$ PUFA consumption is inferior to the recommendations of several international health organizations, which advise consuming one $n$-3 PUFA for five $n$-6 PUFA [55]. Although the intake of $250 \mathrm{mg}$ per day already affords protection against cardiovascular diseases [56], the recommended daily intake of $n-3$ LC-PUFA ranges from 140 to $667 \mathrm{mg} /$ day [57]. Herein, the dietary inclusion of $5 \%$ C. vulgaris in pig diets, supplemented or not with the two CAZyme mixtures, could be an interesting source to supply these beneficial fatty acids to animals and humans, since the usual $n$ - 3 PUFA content in pig muscle is very low (about $0.41-0.68 \mathrm{~g} / 100 \mathrm{~g}$ of total fatty acids) [58]. In opposition to our findings, El-Bahr et al. [59] found higher levels of $n-3$ fatty acids, particularly of EPA and DHA, in breast muscle of broiler chickens fed Spirulina platensis and Amphora coffeaformis compared to those fed C. vulgaris and control birds. Interestingly, fatty acid profile in the microalgae supplemented contrasted with that of poultry meat, since $C$. vulgaris had higher $n-3$ fatty acids than S. platensis and A. coffeaformis [59].

Concerning the ratio of $n-6: n-3$ PUFA, pork from microalga-fed groups had lower values than that from Control group $(-21 \%)$. Although these lower values are more health-protecting to the consumers, they are considerable higher (approximately 12) than the recommended ratio of 4 to prevent cardiovascular diseases [60].

\subsection{Oxidative Stability of Pork}

Table 8 displays the effect of experimental diets on oxidative stability of pig longissimus lumborum muscle after 0,4 , and 8 days of storage at $4{ }^{\circ} \mathrm{C}$. Data showed that for 0 days of storage TBARS are not detected in any group fed with the different experimental diets, as well as for the group fed with $\mathrm{CV}+\mathrm{R}$ diet with 4 days of storage. Although TBARS are detected for the other groups at day 4 , and for all groups after 8 days of storage, experimental diets did not cause significant effects among them with regard to meat oxidative stability $(p>0.05)$. To complement these results, TBARS were also quantified after $0,30,120$, and $300 \mathrm{~min}$ of chemical induction of lipid oxidation, through a ferrous/hydrogen peroxide system. No significant differences were observed among experimental diets for each time of lipid oxidation induction $(p>0.05)$, in spite of a significant increase of TBARS concentration between 0 and $30 \mathrm{~min}$ of lipid oxidation induction $(p=0.0001)$. Figure 1 presents the values of TBARS after 0,30 , 120 , and $300 \mathrm{~min}$ of chemical induction of pork lipid oxidation for each experimental diet. The chemical lipid oxidation induced by the Fenton reaction corroborates the values of TBARS found for pork with the conventional TBARS method. In the current study, all the TBARS values during storage were below to the $0.9 \mathrm{mg}$ malondialdehyde/ $\mathrm{kg}$ of meat reported by Jayasingh and Cornforth [61] for ground and cooked pork meat. TBARS values above $0.5 \mathrm{mg}$ malondialdehyde $/ \mathrm{kg}$ of fresh meat are considered critical because at this level of lipid oxidation rancid odor and taste can be already detected by consumers [62]. Our values were all below this critical point, with exception of pork from $C V+R$ group with eight days of storage, which was slightly higher (0.517). 
Table 8. Effect of experimental diets on oxidative stability of pig longissimus lumborum muscle after 0 , 4 and 8 days of storage at $4{ }^{\circ} \mathrm{C}$.

\begin{tabular}{ccccccc}
\hline $\begin{array}{c}\text { TBARS, } \text { mg } \\
\text { MDA/kg meat }\end{array}$ & Control & CV & CV + R & CV + M & SEM & $p$-Value \\
\hline Day 0 & nd & nd & nd & nd & - & - \\
Day 4 & 0.027 & 0.047 & nd & 0.031 & 0.017 & 0.604 \\
Day 8 & 0.186 & 0.174 & 0.517 & 0.160 & 0.142 & 0.234 \\
\hline
\end{tabular}

Experimental diets: Control-corn-soybean basal diet; CV-basal diet plus 5\% C. vulgaris; CV + R -basal diet plus $5 \%$ C. vulgaris $+0.005 \%$ Rovabio ${ }^{\circledR}$ Excel AP; CV + M-basal diet plus $5 \%$ C. vulgaris $+0.01 \%$ mix of 4 CAZymes. TBARS-Thiobarbituric acid reactive substances; MDA-malonaldehyde; SEM-standard error of the mean; nd-not detected.

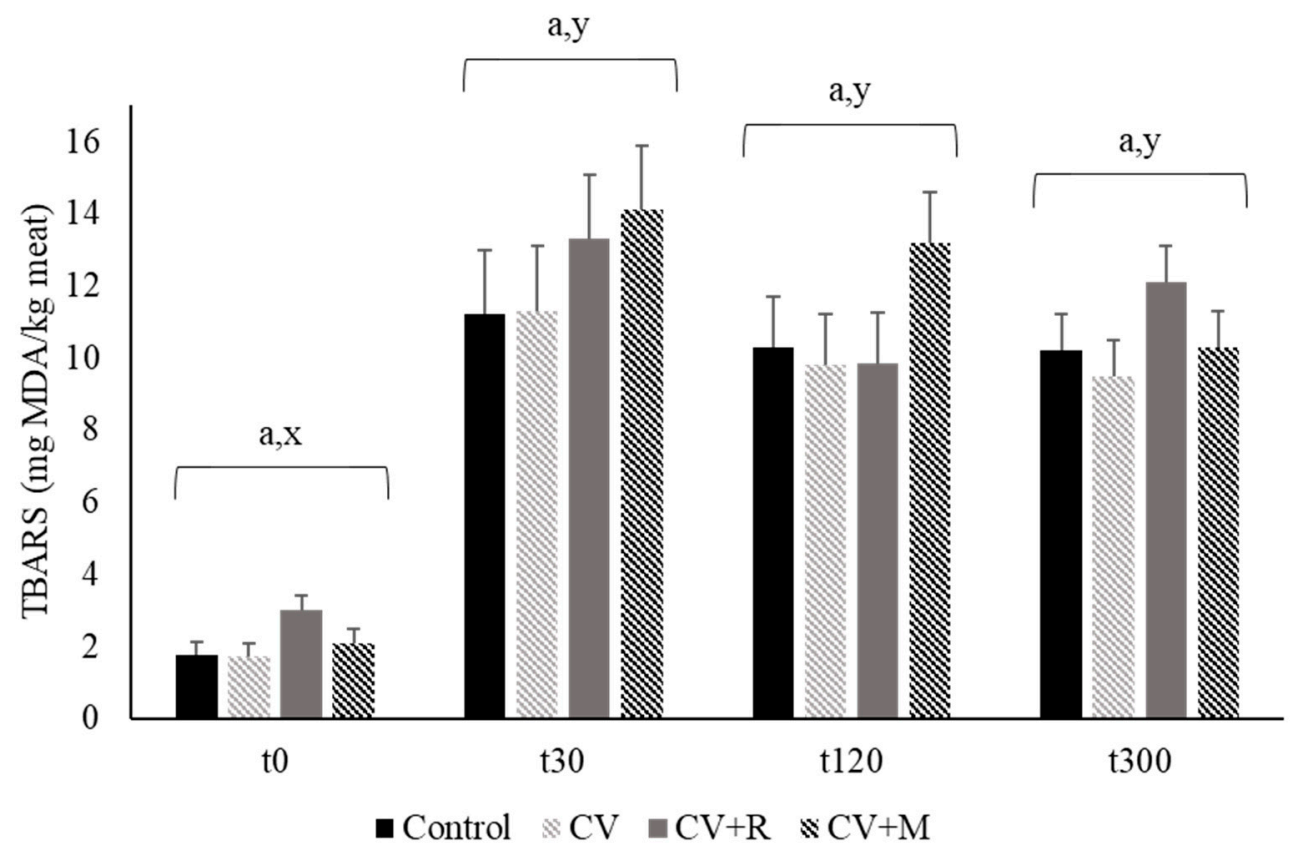

Figure 1. Determination of thiobarbituric acid reactive substances (TBARS) of pig longissimus lumborum muscle after time ( $\mathrm{t} 0, \mathrm{t} 30, \mathrm{t} 120$ and $\mathrm{t} 300 \mathrm{~min}$ ) of chemical induction of lipid oxidation. Experimental diets: Control-corn-soybean basal diet; CV-basal diet plus 5\% C. vulgaris; CV + R -basal diet plus 5\% C. vulgaris $+0.005 \%$ Rovabio ${ }^{\circledR}$ Excel AP; CV + M-basal diet plus 5\% C. vulgaris $+0.01 \%$ mix of 4 CAZymes. Values with different letters within diet (a) and time $(x, y)$ are significantly different $(p<0.05)$.

The inclusion of microalgae rich in antioxidants as natural feed ingredients in animal diet can be a promising and sustainable alternative to enhance not only the nutritional value and health aspects of pork lipids, decreasing the ratio $n-6: n-3$ PUFA, but also delaying meat susceptibility to lipid oxidation [63]. However, PUFA represent the best candidates for the propagation of oxidative reactions that could depreciate the sensory and nutritional properties of foods [64]. Herein, the incorporation of $5 \%$ C. vulgaris in pig diets did not protect pork lipids from peroxidation, which is probably related to similar contents of PUFA, in spite of an important increase of carotenoids in microalga-fed groups in comparison to the control group. Baňoch et al. [46] and Vossen et al. [65] also documented no changes on pork and dry cured ham oxidative stability with the incorporation of $0.0002 \%$ and $0.3-1.2 \%$ levels of Chlorella sp., respectively. Notwithstanding C. vulgaris is an excellent source of antioxidant compounds, such as $\alpha$-tocopherol and carotenoids, as previously documented by Safi et al. [66], the oxidative stability of pork did not reflect the antioxidant activity of $C$. vulgaris. In addition, Müller et al. [67] showed a large variation on the reactivity of the different types of carotenoids toward antioxidant activity. Therefore, changes in antioxidant activity are not only associated to the quantity of 
carotenoids but also with the specific characteristics of carotenoids identity [68]. This aspect deserves further investigation.

\section{Conclusions}

Dietary incorporation of 5\% C. vulgaris did not negatively affect neither growth variables of finishing pigs nor carcass and meat quality traits (physicochemical and sensory analyses). In contrast, the inclusion of this microalga at this level in finishing pig diets improved the nutritional value of pork fat, through the increase of the beneficial lipid-soluble antioxidant pigments and $n-3$ PUFA, as well as the decrease of the $n-6: n-3$ ratio. In addition, the use of carbohydrases in the feed did not improve the digestive utilization of this microalga by pigs, at this incorporation level.

Overall, data indicate that C. vulgaris can be included in finishing pig diets up to $5 \%$, with no need of feed enzymes supplementation, to increase pork fat nutritional value without impairing pig performance. As far as we know, this is the first study depicting the feasibility of the use of C. vulgaris as an alternative sustainable ingredient (incorporation at high levels) in swine feeding. In order to maximize both, the sustainability of swine diets and the pork nutritional quality, further research should be conducted with higher incorporation levels of C. vulgaris, combined or not with exogenous carbohydrases.

Author Contributions: Conceptualization: O.M. and J.A.M.P.; methodology: D.C., J.P., J.M.A., C.M.A., and C.M.G.A.F.; writing-original draft preparation: D.C.; writing-review and editing: J.A.M.P.; project administration: J.A.M.P.; funding acquisition: J.A.M.P. All authors have read and agreed to the published version of the manuscript.

Funding: This work was supported by Fundação para a Ciência e a Tecnologia (FCT, Lisbon, Portugal) grant (PTDC/CVT-NUT/5931/2014), Portugal2020 grant (08/SI/3399/2015), and CIISA (Project UIDB/00276/2020). Author D.C. acknowledge a PhD fellowship (SFRH/BD/126198/2016) and author J.P. (SFRH/BPD/116816/2016) acknowledge a Postdoctoral fellowship, all from FCT.

Acknowledgments: The authors thank Eng. Teresa Costa (Indukern, Lda., Sintra, Portugal) for offering the Rovabio $^{\circledR}$ Excel AP used in this study. The authors are also grateful to Eng. António Sequeira, for zootechnical assistance, and to the Experimental Slaughterhouse staff, for help with carcass data and meat samples collection, from UEISPA (INIAV, Santarém, Portugal).

Conflicts of Interest: The authors declare no conflict of interest.

\section{References}

1. Zhang, M.; Zou, X.; Zhao, D.; Zhao, F.; Li, C. Pork Meat Proteins Alter Gut Microbiota and Lipid Metabolism Genes in the Colon of Adaptive Immune-Deficient Mice. Mol. Nutr. Food Res. 2020, 64. [CrossRef]

2. FAO. The State of Food and Agriculture. 2007. Available online: http://www.fao.org (accessed on 9 September 2020).

3. FAO. The State of Food Insecurity in the World. 2011. Available online: http://www.fao.org (accessed on 9 September 2020).

4. Ekmay, R.; Gatrell, S.; Lum, K.; Kim, J.; Lei, X.G. Nutritional and Metabolic Impacts of a Defatted Green Marine Microalgal (Desmodesmussp.) Biomass in Diets for Weanling Pigs and Broiler Chickens. J. Agric. Food Chem. 2014, 62, 9783-9791. [CrossRef] [PubMed]

5. Taelman, S.E.; De Meester, S.; Van Dijk, W.; Da Silva, V.; Dewulf, J. Environmental sustainability analysis of a protein-rich livestock feed ingredient in The Netherlands: Microalgae production versus soybean import. Resour. Conserv. Recycl. 2015, 101, 61-72. [CrossRef]

6. Morgan, C.A.; Noble, R.C.; Cocchi, M.; McCartney, R. Manipulation of the fatty acid composition of pig meat lipids by dietary means. J. Sci. Food Agric. 1992, 58, 357-368. [CrossRef]

7. Wood, J.D.; Enser, M. Factors influencing fatty acids in meat and the role of antioxidants in improving meat quality. Br. J. Nutr. 1997, 78, S49-S60. [CrossRef] [PubMed]

8. Kaur, G.; Cameron-Smith, D.; Garg, M.; Sinclair, A.J. Docosapentaenoic acid (22:5n-3): A review of its biological effects. Prog. Lipid Res. 2011, 50, 28-34. [CrossRef]

9. Calder, P.C. Omega-3: The good oil. Nutr. Bull. 2017, 42, 132-140. [CrossRef] 
10. Liu, J.; Chen, F. Biology and Industrial Applications of Chlorella: Advances and Prospects. Adv. Biochem. Eng. Biotechnol. 2014, 153, 1-35. [CrossRef]

11. Kotrbáček, V.; Doubek, J.; Doucha, J. The chlorococcalean alga Chlorella in animal nutrition: A review. Environ. Boil. Fishes 2015, 27, 2173-2180. [CrossRef]

12. Batista, A.P.; Gouveia, L.; Bandarra, N.M.; Franco, J.M.; Raymundo, A. Comparison of microalgal biomass profiles as novel functional ingredient for food products. Algal Res. 2013, 2, 164-173. [CrossRef]

13. Baudelet, P.-H.; Ricochon, G.; Linder, M.; Muniglia, L. A new insight into cell walls of Chlorophyta. Algal Res. 2017, 25, 333-371. [CrossRef]

14. Teuling, E.; Wierenga, P.A.; Agboola, J.O.; Gruppen, H.; Schrama, J.W. Cell wall disruption increases bioavailability of Nannochloropsis gaditana nutrients for juvenile Nile tilapia (Oreochromis niloticus). Aquaculture 2019, 499, 269-282. [CrossRef]

15. Son, J.-H.; Ravindran, V. Feed enzyme technology: Present status and future developments. Recent Patents Food Nutr. Agric. 2011, 3, 102-109. [CrossRef] [PubMed]

16. Sander, K.B.; Murthy, G.S. Enzymatic Degradation of Microalgal Cell Walls; American Society of Agricultural and Biological Engineers (ASABE): San Jose, MI, USA, 2009; p. 1.

17. Zheng, H.; Yin, J.; Gao, Z.; Huang, H.; Ji, X.; Dou, C. Disruption of Chlorella vulgaris Cells for the Release of Biodiesel-Producing Lipids: A Comparison of Grinding, Ultrasonication, Bead Milling, Enzymatic Lysis, and Microwaves. Appl. Biochem. Biotechnol. 2011, 164, 1215-1224. [CrossRef]

18. Cho, H.-S.; Oh, Y.-K.; Park, S.-C.; Lee, J.-W.; Park, J.-Y. Effects of enzymatic hydrolysis on lipid extraction from Chlorella vulgaris. Renew. Energy 2013, 54, 156-160. [CrossRef]

19. Gerken, H.G.; Donohoe, B.; Knoshaug, E.P. Enzymatic cell wall degradation of Chlorella vulgaris and other microalgae for biofuels production. Planta 2013, 237, 239-253. [CrossRef]

20. Coelho, D.; Lopes, P.A.; Cardoso, V.; Ponte, P.; Brás, J.; Madeira, M.S.; Alfaia, C.M.; Bandarra, N.M.; Gerken, H.G.; Fontes, C.M.G.A.; et al. Novel combination of feed enzymes to improve the degradation of Chlorella vulgaris recalcitrant cell wall. Sci. Rep. 2019, 9, 5382. [CrossRef]

21. Frederick, K.R. Pork Carcass Evaluation and Procedures; Oklahoma Coop. Ext. Service: Stillwater, OK, USA, 1972.

22. Association of Official Analytical Chemists International. Official Methods of Analysis, 17th ed.; AOAC International: Arlington, VA, USA, 2000.

23. Clegg, K.M. The application of the anthrone reagent to the estimation of starch in cereals. J. Sci. Food Agric. 1956, 7, 40-44. [CrossRef]

24. Noblet, J.; Fortune, H.; Dubois, S.; Henry, Y. Nouvelles Bases D'estimation des Teneurs en Énergie Digestible Métabolisable et Nette des Aliments Pour le Porc; INRA: Paris, France, 1989.

25. Association of Official Analytical Chemists International. Official Methods of Analysis, 18th ed.; AOAC International: Gaithersburg, MD, USA, 2005.

26. Henderson, J.W.; Ricker, R.D.; Bidlingmeyer, B.A.; Woodward, C. Rapid, Accurate, Sensitive and Reproducible Analysis of Amino Acids; Agilent Publication Number 5980-1193EN; Agilent Technologies: Palo Alto, CA, USA, 2000.

27. Sukhija, P.S.; Palmquist, D.L. Rapid method for determination of total fatty acid content and composition of feedstuffs and feces. J. Agric. Food Chem. 1988, 36, 1202-1206. [CrossRef]

28. Prates, J.; Quaresma, M.A.G.; Bessa, R.J.B.; Fontes, C.M.A.; Alfaia, C.M.M. Simultaneous HPLC quantification of total cholesterol, tocopherols and $\beta$-carotene in Barrosã-PDO veal. Food Chem. 2006, 94, 469-477. [CrossRef]

29. Teimouri, M.; Amirkolaie, A.K.; Yeganeh, S. The effects of Spirulina platensis meal as a feed supplement on growth performance and pigmentation of rainbow trout (Oncorhynchus mykiss). Aquaculture 2013, 396, 14-19. [CrossRef]

30. Pestana, J.; Puerta, B.; Santos, H.; Madeira, M.; Alfaia, C.; Lopes, P.; Pinto, R.; Lemos, J.; Fontes, C.; Lordelo, M.; et al. Impact of dietary incorporation of Spirulina (Arthrospira platensis) and exogenous enzymes on broiler performance, carcass traits, and meat quality. Poult. Sci. 2020, 99, 2519-2532. [CrossRef] [PubMed]

31. Hynstova, V.; Sterbova, D.; Klejdus, B.; Hedbavny, J.; Huska, D.; Adamab, V. Separation, identification and quantification of carotenoids and chlorophylls in dietary supplements containing Chlorella vulgaris and Spirulina platensis using High Performance Thin Layer Chromatography. J. Pharm. Biomed. Anal. 2018, 148, 108-118. [CrossRef] [PubMed] 
32. Madeira, M.S.M.D.S.; Costa, P.; Alfaia, C.M.; Lopes, P.A.A.B.; Bessa, R.J.B.; Lemos, J.P.; Prates, J. The increased intramuscular fat promoted by dietary lysine restriction in lean but not in fatty pig genotypes improves pork sensory attributes1. J. Anim. Sci. 2013, 91, 3177-3187. [CrossRef] [PubMed]

33. Hope-Jones, M.; Strydom, P.E.; Frylinck, L.; Webb, E. Effect of dietary beta-agonist treatment, vitamin D3 supplementation and electrical stimulation of carcasses on colour and drip loss of steaks from feedlot steers. Meat Sci. 2012, 90, 607-612. [CrossRef]

34. Honikel, K.O. Reference methods for the assessment of physical characteristics of meat. Meat Sci. 1998, 49, 447-457. [CrossRef]

35. Oillic, S.; Lemoine, E.; Gros, J.-B.; Kondjoyan, A. Kinetic analysis of cooking losses from beef and other animal muscles heated in a water bath-Effect of sample dimensions and prior freezing and ageing. Meat Sci. 2011, 88, 338-346. [CrossRef]

36. American Meat Science Association. Research Guidelines for Cookery, Sensory Evaluation, and Instrumental Tenderness Measurements of Meat, 2nd ed.; AMSA: Champaign, IL, USA, 2016.

37. Cross, H.R.; Moen, R.; Stanfield, M.S. Training and testing of judges for sensory analysis of meat quality. Food Technol. 1979, 32, 48-54.

38. Almeida, J.M.; Bressan, M.C.; Santos-Silva, J.; Moreira, O.; Bettencourt, C.; Da Gama, L.T. Physicochemical characteristics and sensory attributes of meat from heavy-weight Iberian and F1 Large White $\times$ Landrace pigs finished intensively or in free-range conditions. J. Anim. Sci. 2018, 96, 2734-2746. [CrossRef]

39. Belk, K.E.; Dikeman, M.E.; Calkins, C.R.; Andy King, D.; Shackelford, S.D.; Hale, D. Research Guidelines for Cookery, Sensory Evaluation, and Instrumental Tenderness Measurements of Meat; American Meat Science Association: Champaign, IL, USA, 2015; pp. 6-104.

40. Folch, J.; Lees, M.; Stanley, G.S. A simple method for the isolation and purification of total lipides from animal tissues. J. Biol. Chem. 1957, 226, 497-509.

41. Raes, K.; De Smet, S.; Demeyer, D. Effect of double-muscling in Belgian Blue young bulls on the intramuscular fatty acid composition with emphasis on conjugated linoleic acid and polyunsaturated fatty acids. Anim. Sci. 2001, 73, 253-260. [CrossRef]

42. Madeira, M.S.M.D.S.; Pires, V.M.R.; Alfaia, C.M.; Luxton, R.; Doran, O.; Bessa, R.J.B.; Prates, J. Combined effects of dietary arginine, leucine and protein levels on fatty acid composition and gene expression in the muscle and subcutaneous adipose tissue of crossbred pigs. Br. J. Nutr. 2014, 111, 1521-1535. [CrossRef] [PubMed]

43. Grau, A.; Guardiola, F.; Boatella, J.; Barroeta, A.C.; Codony, R. Measurement of 2-thiobarbituric acid values in dark chicken meat through derivative spectrophotometry: Influence of various parameters. J. Agric. Food Chem. 2000, 48, 1155-1159. [CrossRef] [PubMed]

44. Mercier, Y.; Gatellier, P.; Renerre, M. Lipid and protein oxidation in vitro, and antioxidant potential in meat from Charolais cows finished on pasture or mixed diet. Meat Sci. 2004, 66, 467-473. [CrossRef]

45. Yan, L.; Lim, S.U.; Kim, I. Effect of Fermented Chlorella Supplementation on Growth Performance, Nutrient Digestibility, Blood Characteristics, Fecal Microbial and Fecal Noxious Gas Content in Growing Pigs. Asian Australas. J. Anim. Sci. 2012, 25, 1742-1747. [CrossRef]

46. Baňoch, T.; Svoboda, M.; Kuta, J.; Saláková, A.; Fajt, Z. The effect of iodine from iodine-enriched alga Chlorella spp. on the pork iodine content and meat quality in finisher pigs. Acta Veter Brno 2012, 81, 339-346. [CrossRef]

47. Furbeyre, H.; Van Milgen, J.; Mener, T.; Gloaguen, M.; Labussière, E. Effects of dietary supplementation with freshwater microalgae on growth performance, nutrient digestibility and gut health in weaned piglets. Animal 2017, 11, 183-192. [CrossRef]

48. Furbeyre, H.; Van Milgen, J.; Mener, T.; Gloaguen, M.; Labussière, E. Effects of oral supplementation with Spirulina and Chlorella on growth and digestive health in piglets around weaning. Animal 2018, 12, 2264-2273. [CrossRef]

49. Oh, S.T.; Zheng, L.; Kwon, H.J.; Choo, Y.K.; Lee, K.W.; Kang, C.W.; An, B.K. Effects of Dietary Fermented Chlorella vulgaris $\left(\mathrm{CBT}^{\circledR}\right)$ on Growth Performance, Relative Organ Weights, Cecal Microflora, Tibia Bone Characteristics, and Meat Qualities in Pekin Ducks. Asian Australas. J. Anim. Sci. 2014, 28, 95-101. [CrossRef]

50. Nogareda, C.; Moreno, J.A.; Angulo, E.; Sandmann, G.; Portero, M.; Capell, T.; Zhu, C.; Christou, P. Carotenoid-enriched transgenic corn delivers bioavailable carotenoids to poultry and protects them against coccidiosis. Plant. Biotechnol. J. 2016, 14, 160-168. [CrossRef] 
51. Gouveia, L.; Veloso, V.; Reis, A.; Fernandas, H.; Novais, J.; Empis, J. Chlorella vulgaris used to colour egg yolk. J. Sci. Food Agric. 1996, 70, 167-172. [CrossRef]

52. Lemahieu, C.; Bruneel, C.; Termote-Verhalle, R.; Muylaert, K.; Buyse, J.; Foubert, I. Impact of feed supplementation with different omega-3 rich microalgae species on enrichment of eggs of laying hens. Food Chem. 2013, 141, 4051-4059. [CrossRef] [PubMed]

53. Mason, R.P. New Insights into Mechanisms of Action for Omega-3 Fatty Acids in Atherothrombotic Cardiovascular Disease. Curr. Atheroscler. Rep. 2019, 21, 1-11. [CrossRef]

54. Shahidi, F.; Ambigaipalan, P. Omega-3 Polyunsaturated Fatty Acids and Their Health Benefits. Annu. Rev. Food Sci. Technol. 2018, 9, 345-381. [CrossRef] [PubMed]

55. Agence Nationale de Sécurité Sanitaire de L'alimentation, de L'environnement et du Travail. Actualisation des Apports Nutritionnels Conseillés Pour les Acides Gras; ANSES: Maisons-Alfort, France, 2011.

56. Kris-Etherton, P.M.; Grieger, J.A.; Etherton, T.D. Dietary reference intakes for DHA and EPA. Prostaglandins Leukot. Essent. Fat. Acids 2009, 81, 99-104. [CrossRef]

57. Molendi-Coste, O.; Legry, V.; Leclercq, I.A. Why and How Meet n-3 PUFA Dietary Recommendations? Gastroenterol. Res. Pr. 2010, 2011, 1-11. [CrossRef]

58. Domínguez, R.; Pateiro, M.; Gagaoua, M.; Barba, F.J.; Zhang, W.; Lorenzo, J.M. A Comprehensive Review on Lipid Oxidation in Meat and Meat Products. Antioxidants 2019, 8, 429. [CrossRef]

59. El-Bahr, S.M.; Shousha, S.; Shehab, A.; Khattab, W.; Ahmed-Farid, O.; Sabike, I.; El-Garhy, O.; Albokhadaim, I.; Al-Busada, K.A. Effect of Dietary Microalgae on Growth Performance, Profiles of Amino and Fatty Acids, Antioxidant Status, and Meat Quality of Broiler Chickens. Animal 2020, 10, 761. [CrossRef]

60. HMSO, UK. Department of Health. Nutritional aspects of cardio-vascular disease. Rep. Health Soc. Subj. 1994, 46, 37-46.

61. Jayasingh, P.; Cornforth, D.P. Comparison of antioxidant effects of milk mineral, butylated hydroxytoluene and sodium tripolyphosphate in raw and cooked ground pork. Meat Sci. 2004, 66, 83-89. [CrossRef]

62. Wood, J.D.; Enser, M.; Fisher, A.V.; Nute, G.R.; Sheard, P.R.; Richardson, R.I.; Hughes, S.I.; Whittington, F.M. Fat deposition, fatty acid composition and meat quality: A review. Meat Sci. 2008, 78, 343-358. [CrossRef]

63. Wojtasik-Kalinowska, I.; Guzek, D.; Górska-Horczyczak, E.; Brodowska, M.; Sunabcd, D.-W.; Wierzbicka, A. Diet with linseed oil and organic selenium yields low n-6/n-3 ratio pork Semimembranosus meat with unchanged volatile compound profiles. Int. J. Food Sci. Technol. 2018, 53, 1838-1846. [CrossRef]

64. Martini, S.; Tagliazucchi, D.; Minelli, G.; Fiego, D.P.L. Influence of linseed and antioxidant-rich diets in pig nutrition on lipid oxidation during cooking and in vitro digestion of pork. Food Res. Int. 2020, 137, 109528. [CrossRef]

65. Vossen, E.; Raes, K.; Van Mullem, D.; De Smet, S. Production of docosahexaenoic acid (DHA) enriched loin and dry cured ham from pigs fed algae: Nutritional and sensory quality. Eur. J. Lipid Sci. Technol. 2017, 119, 1600144. [CrossRef]

66. Safi, C.; Zebib, B.; Merah, O.; Pontalier, P.-Y.; Vaca-Garcia, C. Morphology, composition, production, processing and applications of Chlorella vulgaris: A review. Renew. Sustain. Energy Rev. 2014, 35, 265-278. [CrossRef]

67. Müller, L.; Fröhlich, K.; Böhm, V. Comparative antioxidant activities of carotenoids measured by ferric reducing antioxidant power (FRAP), ABTS bleaching assay ( $\alpha$ TEAC), DPPH assay and peroxyl radical scavenging assay. Food Chem. 2011, 129, 139-148. [CrossRef]

68. Goiris, K.; Muylaert, K.; Fraeye, I.; Foubert, I.; De Brabanter, J.; De Cooman, L. Antioxidant potential of microalgae in relation to their phenolic and carotenoid content. Environ. Boil. Fishes 2012, 24, 1477-1486. [CrossRef]

Publisher's Note: MDPI stays neutral with regard to jurisdictional claims in published maps and institutional affiliations. 